\title{
Можливість хірургічного лікування хворих на розшаровуючу аневризму висхідної аорти в умовах помірної гіпотермії
}

\author{
Бойко В. В., Бучнєва О. В., Шафер Я. В., Пісклова Ю. В., Богун Ю. В., \\ Крилова О. С., Крючков Є. Д., Ткач О.І.
}

ДУ «Інститут загальної та невідкладної хірургії імені В.Т. Зайцева НАМН» (Харків)

\begin{abstract}
На сьогоднішній день залишаються актуальними питання щодо виду оперативного втручання при розшаровуючій аневризмі аорти типу А, температурного режиму та застосування глибокої гіпотермії або циркулярної зупинки кровообігу під час оперативних втручань на дузі аорти. Беззаперечним є факт зниження ризику післяопераційних ускладнень у пацієнтів, що перенесли оперативне втручання без застосування глибокої гіпотермії або циркулярної зупинки кровообігу. Ризик оперативного втручання у пацієнтів із розшаровуючою аневризмою аорти зумовлений у більшості випадків саме необхідністю глибокої гіпотермії для виконання оперативного втручання на дузі аорти.

На базі ДУ «ІЗНХ імені В. Т. Зайцева НАМН» було прооперовано 52 пацієнти з розшаровуючою аневризмою аорти, з них 28 пацієнтів - із діагнозом розшаровуюча аневризма аорти типу А в умовах помірної гіпотермії.
\end{abstract}

Ключові слова: розшаровуюча аневризма висхідної аорти, супракоронарне протезування аорти, антеградна перфузія головного мозку.

Сучасні діагностичні технології, збільшення тривалості життя, поширеність гіпертонічної хвороби зумовлюють зростання гострого розшарування аорти.

Перше описання розшарування аорти проведено в 1771 році в роботі «De Sedibus» доктором Morgagni, a перше оперативне втручання з приводу розшарування висхідної аорти здійснено в 1955 році De-Bakey.

Єдиною можливістю врятувати життя хворому з розшаруванням аорти типу А (за Stanford) $є$ оперативне втручання. Незважаючи на вдосконалення медичного забезпечення, привертають увагу високі цифри післяопераційної летальності як у ранньому, так і пізньому післяопераційному періоді. Крім цього, частота післяопераційних ускладнень також залишається високою порівняно з іншими видами кардіохірургічних операцій. За даними різних авторів, госпітальна летальність становить від 15 до $20 \%$.

За останній період відбулося вдосконалення можливостей діагностики, моніторингу, технічного забезпечення оперативного лікування. Паралельно зазнавала змін і хірургічна тактика лікування пацієнтів із розшаруванням аорти. Дискутабельною є тактика захисту внутрішніх органів під час оперативного втручання. I дотепер залишається актуальним питання стосовно необхідності стискання аорти або використання відкритої техніки. Немає єдиної думки про використання певного температурного режиму. Питання про застосування глибокої гіпотермії також продовжує обгово- рюватися, хоча визнається багатьма хірургами як необхідність.

Мета роботи - оцінити можливість лікування пацієнтів із розшаровуючою аневризмою висхідного відділу аорти типу А в умовах помірної гіпотермії.

Матеріали та методи. Протягом 2012-2018 рр. у ДУ «ІЗНХ імені В. Т. Зайцева НАМН» прооперовано 52 хворих із діагнозом розшаровуюча аневризма аорти типу А. Чоловіків було 40 (77\%), жінок - 12 (23\%). Вік хворих коливався в межах 32-76 років, середній -54 роки. Одна пацієнтка була оперована в підгострій стадії розшарування, 51 пацієнт - в гострій (час - від моменту розшарування до двох тижнів), з них 36 пацієнтів оперовані в період до 5 днів від розшарування.

Основною причиною несприятливих результатів оперативного лікування хворих із розшаровуючою аневризмою аорті типу А була гіпокоагуляційна кровотеча у $11(68,7 \%)$. Всі ці хворі були прооперовані в умовах глибокої гіпотермії та унілатеральної селективної антеградної перфузії головного мозку в техніці відкритої аорти (19 пацієнтів) і один пацієнт - в умовах циркулярної зупинки кровообігу. Також у цій групі хворих найбільш часто зустрічалися неврологічні ускладнення різного ступеня прояву (у 19 пацієнтів). Тривалість операції при використанні методики глибокої гіпотермії становила в середньому 8 г. \pm 45 хв.

3 огляду на тривалість перебування в реанімації $8 \pm 1$ доба і тривалість штучної вентиляції легень $(60,8 \pm 59,8$ год.), з 2016 року ми почали надавати пере- 
вагу операційним втручанням без використання глибокої гіпотермії.

Для забезпечення артеріальної перфузії до стернотомії проводилась канюляція в ліву підключичну та стегнову артерію (вибір сторони канюляції залежав від анатомії ураження черевної аорти і клубових артерій). Після цього проводилася стернотомія, венозна канюляція, підключення апарату штучного кровообігу, установка лівошлуночкового дренажу. Аорта виділялася до рівня низхідної, брахіоцефальні судини оброблялися та обходилися з використанням турнікетів. Штучний кровообіг проводився за стандартною методикою. Кардіоплегія здійснювалася розчином Del-Nido селективно антеградно, лише в одному випадку - ретроградно. Всі маніпуляції виконувалися в умовах помірної гіпотермії з температурою пацієнта 28-30 єС. Ревізія дуги проводилася після оклюзії на турнікетах брахіоцефальних суди, у момент узгодженої зупинки ШК, тривала $35 \pm 12$ с. Після цього приймалося рішення щодо подальшої тактики оперативного лікування. Якщо потреби в протезуванні дуги аорті не було, виконувалося лише протезування висхідної аорти. Якщо пацієнт потребував протезування $\mathbf{S}$ дуги, то брахіоцефальні судини, що потенційно залишались у «відкритій аорті», затискалися турнікетами, а аортальним затискувачем перетискалася аорта нижче місця розриву аорти. Всі інші маніпуляції проводилися за стандартною методикою. Зручність для хірурга у виконанні дистального анастомозу залежить від якості виділення аорти.

Результати та обговорення. За період з 2012 року нами було прооперовано 45 хворих із розшаровуючою аневризмою аорти типу А, з них 21 пацієнт - за методикою використання помірної гіпотермії. Лише в одного хворого вона не була використана, оскільки супутнім захворюванням була аневризма черевної аорти з пристінковим тромбозом. Смертність у цій групі склала 9,5\% (2 пацієнти), але пов'язана вона з патологією коронарних артерій i, як наслідок, синдромом малого серцевого викиду. Кровотеча відмічена у 1 хворого і, найбільш вірогідно, пов'язана з прийомом антиагрегантів у передопераційному періоді. Неврологічні порушення в післяопераційному періоді мали менше проявів і зустрічалися у $3(14,28 \%)$ пацієнтів. Тривалість оперативного втручання скоротилася до $6 \pm 0,5$ год., також скоротився час перебування в реанімаційному відділенні - до $5 \pm 2$ доби. Тривалість штучної вентиляції легень знизилася до $38,8 \pm 28,5$ год.

Висновки. Таким чином, хворі з розшаровуючою аневризмою аорти типу А, стабільні за показниками гемодинаміки, переважною більшістю можуть бути прооперовані в умовах помірної гіпотермії, що дозволяе зменшити ризик небезпечних ускладнень, пов'язаних із використанням глибокої гіпотермії.

\section{Література}

1. Непосредственные и отдаленные результаты хирургического лечения аневризм и расслоений восходящего отдела и дуги аорты / Ю. В. Белов, А. Б. Степаненко, Ф. В. Кузнечевский // Российский кардиологический журнал. 2004. № 5:5-16.

2. Технологии хирургического лечения аневризм грудного и торакоабдоминального отделов аорты / Ю. В. Белов, А. Б. Степаненко, А. П. Гене, Ф. Ф. Хамитов, Ф. В. Кузнечевский, Г. Р. Григорян / Анналы Российского научного центра хирургии РАМН. 2001 г. Выпуск № 10: 22-29.

3. Хирургическое лечение аневризм и расслоений восходящего отдела и дуги аорты. Ф. В. Кузнечевский / Российский кардиологический журнал. 2002 г. № 6: $92-101$.

4. Хирургическое лечение гигантских аневризм восходящего отдела и дуги аорты в условиях глубокой гипотермии и остановки кровообращения с периферическим подключением аппарата искусственного кровообращения / Ю. В. Белов. А. П. Гене, А. Б. Степаненко, Л. С. Локшин, Г. В. Бабалян, Ф. В. Кузнечевский, М. В. Кириллов / Хирургия. 2003 г. №5:4-8.

5. Acute aortic dissection: pathogenesis, risk factors and diagnosis. Gawinecka Joannaa, Schцnrath Felixb, von Eckardstein Arnolda a Institute of the Clinical Chemistry/ University Hospital Zurich, Switzerland Department of Cardiac, Thoracic and Vascular Surgery, German Heart Institute, Berlin, Germany / Review article: Biomedical Intelligence / Published 25 August 2017 /doi:10.4414/ smw.2017.14489 Cite this as: Swiss Med Wkly. 2017;147.

6. Clinical features and prognosis of patients with acute aortic dissection in China / Lujing Zhao, Yanfen Chai, Zhigang Li / Emergency Department of Tianjin 4th Center Hospital, China, /Volume: 45 issue: 2, page(s): 823-829, https://doi. org/10.1177/0300060517699319. Issue published: April 1, 2017.

7. A Contemporary Review of Acute Aortic Dissection/ Subhi J Al'Aref, Leonard N Girardi, Richard Devereux, Christopher Lau, Bobby D Ghosh, Rajesh V Swaminathan, Dmitriy N Feldman, Luke K Kim1, Geoffrey Bergman, Robert M Minutello, S Chiu Wong, Harsimran S Singh/ Division of Cardiology, Department of Medicine. NewYork Presbyterian Hospital - Weill Cornell Medical Center/ New York, NY 10065, Department of Cardiothoracic Surgery. NewYork Presbyterian Hospital - Weill Cornell Medical Center/ New York, NY 10065, Published date: July 14, 2015.

8. Mortality in patients with acute aortic dissection type A: analysis of pre- and intraoperative risk factors from the German Registry for Acute Aortic Dissection Type A (GERAADA)/ Lars Oliver Conzelmanna, Ernst Weigangb, Uwe Mehlhorna, Ahmad Abugamehd, Isabell Hoffmanne, Maria Blettnere, Christian D. Etzb, Martin Czernyb, and Christian F. Vahld / European Journal of Cardio-Thoracic Surgery 49 (2016)/ e44-e52 doi:10.1093/ejcts/ezv356 / Advance Access publication 28 October 2015. 


\title{
Possibility of acute ascending aortic dissection treatment with moderate hypothermic circulatory arrest
}

\author{
Boiko V. V., Buchnieva O. V., Shafer Y. V., Pisklova Y.V., Krylova O. S., Kriuchkov Y. D., Tkach O. I. \\ ST “Zaycev V. T. Institute of General and Urgent Surgery AMS of Ukraine” (Kharkiv)
}

The issues considering the type of surgical treatment for acute aortic dissection, the temperature mode and the use of circulatory arrest during surgeries on thoracic aorta are of current importance today. It is undisputed that the risks of postoperative complications decrease among patients who underwent surgery without circulatory arrest. Surgical risks among patients with acute aortic dissections is mostly due to the necessity of deep hypothermia for circulatory arrest. In ST "Zaycev V. T. Institute of General and Urgent Surgery AMS of Ukraine" 21 patients with acute ascending aortic dissections underwent surgery using moderate hypothermic circulatory arrest.

Key words: acute ascending aortic dissection, supracoronary ascending aorta replacement, antegrade cerebral perfusion. 